\title{
The Pakistan Risk of Myocardial Infarction Study: a resource for the study of genetic, lifestyle and other determinants of myocardial infarction in South Asia
}

\author{
Danish Saleheen · Moazzam Zaidi · Asif Rasheed • Usman Ahmad • Abdul Hakeem • \\ Muhammed Murtaza · Waleed Kayani · Azhar Faruqui · Assadullah Kundi · \\ Khan Shah Zaman · Zia Yaqoob - Liaquat Ali Cheema · Abdus Samad - Syed Zahed Rasheed • \\ Nadeem Hayat Mallick · Muhammad Azhar · Rashid Jooma • Ali Raza Gardezi • \\ Nazir Memon · Abdul Ghaffar · Fazal-ur-Rehman · Nadir Khan · Nabi Shah • \\ Asad Ali Shah · Maria Samuel · Farina Hanif · Madiha Yameen · Sobia Naz • \\ Aisha Sultana · Aisha Nazir · Shehzad Raza · Muhammad Shazad - Sana Nasim • \\ Muhammad Ahsan Javed · Syed Saadat Ali · Mehmood Jafree · Muhammad Imran Nisar • \\ Muhammad Salman Daood · Altaf Hussain · Nadeem Sarwar · Ayeesha Kamal · \\ Panos Deloukas · Muhammad Ishaq · Philippe Frossard · John Danesh
}

Received: 22 October 2008/Accepted: 11 March 2009/Published online: 30 April 2009

(C) The Author(s) 2009. This article is published with open access at Springerlink.com

\begin{abstract}
The burden of coronary heart disease (CHD) is increasing at a greater rate in South Asia than in any other region globally, but there is little direct evidence about its determinants. The Pakistan Risk of Myocardial Infarction Study (PROMIS) is an epidemiological resource to enable reliable study of genetic, lifestyle and other determinants of
\end{abstract}

D. Saleheen · A. Rasheed · U. Ahmad · M. Ishaq · P. Frossard Center for Non-Communicable Diseases (CNCD), Karachi, Pakistan

D. Saleheen $(\bowtie) \cdot$ N. Sarwar · J. Danesh

Department of Public Health and Primary Care, Strangeways Research Laboratory, University of Cambridge, Cambridge CB1 $8 \mathrm{RN}, \mathrm{UK}$

e-mail: ds436@medschl.cam.ac.uk

D. Saleheen · M. Zaidi · A. Rasheed · U. Ahmad · A. Hakeem - M. Murtaza - W. Kayani - N. Khan - N. Shah ·

A. A. Shah - M. Samuel - F. Hanif - M. Yameen - S. Naz ·

A. Sultana - A. Nazir - S. Raza - M. Shazad - S. Nasim

M. A. Javed - S. S. Ali · M. Jafree · M. I. Nisar - A. Hussain ·

P. Frossard

Department of Biological and Biomedical Sciences, Aga Khan

University, Stadium road, Karachi, Pakistan

A. Faruqui · A. Kundi · K. S. Zaman · Z. Yaqoob ·

L. A. Cheema

National Institute of Cardiovascular Diseases, Karachi, Pakistan

A. Samad · S. Z. Rasheed · M. Ishaq

Karachi Institute of Heart Diseases, Karachi, Pakistan
CHD in South Asia. By March 2009, PROMIS had recruited over 5,000 cases of first-ever confirmed acute myocardial infarction (MI) and over 5,000 matched controls aged 30-80 years. For each participant, information has been recorded on demographic factors, lifestyle, medical and family history, anthropometry, and a 12-lead

N. H. Mallick · M. Azhar - M. S. Daood

Punjab Institute of Cardiology, Lahore, Pakistan

R. Jooma

Jinnah Post-graduate Medical Centre, Karachi, Pakistan

A. R. Gardezi

Multan Institute of Cardiology, Multan, Pakistan

N. Memon · A. Ghaffar

Civil Hospital, Hyderabad, Pakistan

Fazal-ur-Rehman

Red Crescent Institute of Cardiology, Hyderabad, Pakistan

A. Kamal

Section of Neurology, Department of Medicine, Aga Khan University, Karachi, Pakistan

P. Deloukas

Wellcome Trust Sanger Institute, Hinxton, Cambridge, UK 
electrocardiogram. A range of biological samples has been collected and stored, including DNA, plasma, serum and whole blood. During its next stage, the study aims to expand recruitment to achieve a total of about 20,000 cases and about 20,000 controls, and, in subsets of participants, to enrich the resource by collection of monocytes, establishment of lymphoblastoid cell lines, and by resurveying participants. Measurements in progress include profiling of candidate biochemical factors, assay of 45,000 variants in 2,100 candidate genes, and a genomewide association scan of over 650,000 genetic markers. We have established a large epidemiological resource for CHD in South Asia. In parallel with its further expansion and enrichment, the PROMIS resource will be systematically harvested to help identify and evaluate genetic and other determinants of MI in South Asia. Findings from this study should advance scientific understanding and inform regionally appropriate disease prevention and control strategies.

Keywords Myocardial Infarction - Case-control study · South Asia · Pakistan · MI · Risk factors

\section{Introduction}

Coronary heart disease (CHD) is the single leading cause of death worldwide and a major cause of disability [1]. The projected increase in CHD is expected to be much greater in South Asia than in any other region worldwide [2], where it is expected to more than double over the next 20 years [3]. The burden of CHD in South Asians extends beyond regional concerns, as CHD mortality and morbidity remain higher in immigrant South Asians living in western regions compared with native western populations [4]. There is limited evidence, however, about the determinants of CHD in South Asia, although such evidence should contribute importantly to scientific understanding and to the development of regionally appropriate strategies to prevent and control CHD. In particular, it has been proposed that populations in South Asia are predisposed to cardiometabolic conditions owing to a combination of hereditary and lifestyle factors that promote metabolic dysfunction [5, 6], but direct evidence is sparse.

Until the initiation of the Pakistan Risk of Myocardial Infarction Study (PROMIS), fewer than 1,000 patients and a similar number of controls had been assessed in all available epidemiological studies of CHD in Pakistan, a country with a population of 175 million. The value of large case-control studies of CHD in relation to genetic and lifestyle factors has been demonstrated in non-Pakistani populations by ISIS (14,000 cases of acute myocardial infarction (MI), 16,000 controls: $>95 \%$ white British) [7] and INTERHEART (15,000 acute MI cases, 15,000 controls: $<5 \%$ Pakistani) [8]. An important challenge is, therefore, to establish epidemiological resources of considerable scale in a rigorous yet cost-effective manner in South Asian populations where there is unmet scientific and public health need.

The objectives of this report are to describe the methods used in the establishment of a epidemiological resource for the study of CHD in Pakistan and to outline the rationale for the study's plan of further expansion and sub-studies to enable scientific enrichment.

\section{Methods}

\section{Study participants}

PROMIS is a retrospective case-control study of acute MI. Following screening by medically-qualified research officers, patients aged 30-80 years admitted to the emergency rooms of collaborating hospitals (Fig. 1 lists recruitment centres active as of March 2009) have been eligible for inclusion as cases if they fulfil all of the following criteria: (1) sustained clinical symptoms suggestive of MI lasting longer than $20 \mathrm{~min}$ within the previous $24 \mathrm{~h}$; (2) ECG changes of MI (i.e., new pathologic Q waves, at least $1 \mathrm{~mm}$ ST elevation in any 2 or more contiguous limb leads or a new left bundle branch block, or new persistent ST-T wave changes diagnostic of a non-Q wave MI); (3) confirmatory troponin-T measurements; and (4) no previous cardiovascular diseases, defined as self-reported history of angina, MI, coronary revascularisation, transient ischaemic attack, stroke or evidence of $\mathrm{CHD}$ on prior ECG or in other medical records.

Controls have been individuals without a self-reported history of cardiovascular disease (who had no ECG changes consistent with a previous MI) drawn from individuals concurrently identified in the same hospitals as index cases. Controls have been recruited in the following order of priority: (1) visitors of patients attending the out-patient department; (2) patients attending the out-patient department for routine non-cardiac complaints, or (3) non-blood related visitors of index MI cases. Controls were frequency-matched to cases on sex and age (in 5-year bands). Participants were not recruited into PROMIS if any of the following features were evident: (1) a previous history of cardiovascular disease (including self-reported MI, angina, coronary revascularization, stroke, transient ischaemic attack, or peripheral vascular disease, and, in cases, presence of cardiogenic shock); (2) a history of a viral or bacterial infection in the previous 2 weeks; (3) documented chronic conditions, such as malignancy, any chronic infection, leprosy, malaria or other bacterial/parasitic infections, chronic inflammatory disorders, hepatitis or 


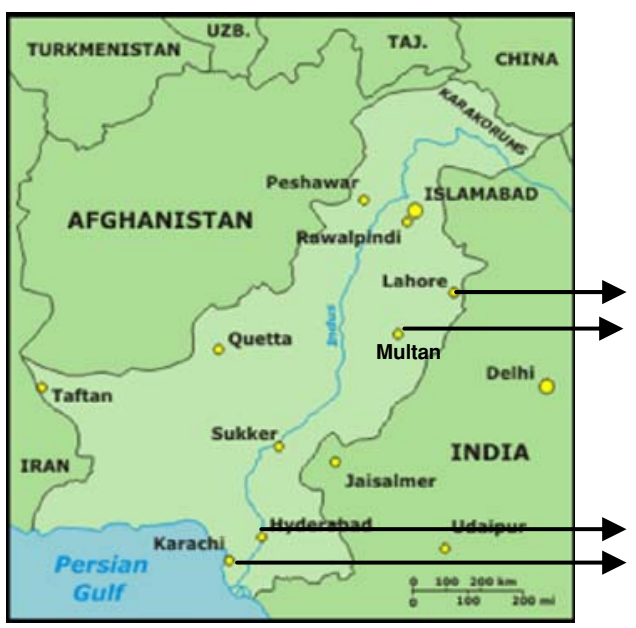

\author{
Recruitment centre \\ Punjab Institute of Cardiology \\ Multan Institute of Cardiology \\ Civil Hospital \\ Red Crescent Hospital \\ National Institute of Cardiovascular Diseases \\ Karachi Institute of Heart Diseases
}

City

Predominant

ethnicity

Lahore Punjabi

Multan Punjabi

Hyderabad Sindhi

Hyderabad Urdu

Karachi Urdu

Karachi Urdu

Fig. 1 Location and predominant ethnicities of PROMIS recruitment centres

renal failure on past medical history; (4) pregnancy; or (5) refusal to give consent.

Prior to adoption of the approach described above for the selection of controls, we carefully assessed several other options, such as choosing reference groups who had: an unrelated disease; population based community controls; controls from occupational settings or health-check clinics. Our chosen approach was considered desirable because it achieved a balance between feasibility and scientific rigor and because it was scalable in Pakistan. (By contrast, whereas use of population based community controls may be desirable in principle, it is considerably more labour-intensive and expensive and cannot guarantee that such controls will necessarily represent the catchment areas from which hospital-based cases are derived, particularly since referral patterns to hospitals are complex.) Furthermore, by analogy with the Wellcome Trust CaseControl Consortium (WTCCC) [9], PROMIS controls can be efficiently and validly used for patients with other cardiometabolic conditions owing to the broad geographical and ethnic scope in PROMIS.

PROMIS has received approval by the relevant research ethics committee of each of the institutions involved in participant recruitment. Informed consent has been obtained from each participant recruited into the study, including for use of samples in genetic, biochemical and other analyses.

\section{Questionnaire administration and anthropometry}

To maximise consistency and quality-control across recruitment centres, staff in each recruitment centre have been trained in the use of standard operating procedures. Research medical officers have administered pre-piloted epidemiological questionnaires to participants that seek a total of $>200$ items of information in relation to: ethnicity (e.g, personal and paternal ethnicity, spoken language, place of birth and any known consanguinity); demographic characteristics; lifestyle factors (e.g., tobacco and alcohol consumption, dietary intake and physical activity); and personal and family history of cardiovascular disease; and medication usage (Table 1). As dietary habits and types of tobacco consumption, in particular, can be substantially different in South Asia than in western populations, it has been necessary to develop a locally relevant questionnaire that adequately records such information (Table 2). Development of the dietary component of this questionnaire involved completion of a $24 \mathrm{~h}$ dietary recall questionnaire and the completion of a 7-day food diary by 200 healthy adults, which enabled the identification of 160 different foods consumed that were categorised into 54 groups by a local nutritionist. A provisional food-frequency questionnaire was then further refined after its piloting among 100 additional healthy adults (e.g., the final version added further questions about foods typically consumed only during Ramadan, the month of fasting). For MI cases, questionnaires have been administered only after medical stabilization and relate to habits and characteristics during the time before the diagnosis of acute MI. Using standardized procedures and equipment, research officers have obtained measurements of height, weight, waist and hip circumference, systolic and diastolic blood pressure, and heart rate. Waist circumference has been assessed over the abdomen at the widest diameter between the costal margin and the iliac crest, and hip circumference has been assessed at the level of the greater trochanters. Research officers have also recorded a standard 12-lead ECG. Information extracted from questionnaires, physical measurements and ECG recordings has been entered by two different operators 
Table 1 Summary of questionnaire-based information collected

\begin{tabular}{|c|c|}
\hline Type of information & Detail recorded \\
\hline $\begin{array}{l}\text { Symptoms, arrival and management } \\
\text { at the hospital }\end{array}$ & $\begin{array}{l}\text { Date of MI, time of onset, time since last meal, review of symptoms, diagnosis and management at the } \\
\text { hospital and any investigations ordered by the attending physician }\end{array}$ \\
\hline Medication and medical history & $\begin{array}{l}\text { Medication class and duration of use for each of anti-coagulant, blood pressure- and lipid-lowering, } \\
\text { diabetes related, hormonal and, for women, contraceptive and HRT medications }\end{array}$ \\
\hline Female reproductive history & $\begin{array}{l}\text { Age at first menstrual period, age periods stopped, hormones for menopause treatment, oral contraceptive } \\
\text { use }\end{array}$ \\
\hline Family history & $\begin{array}{l}\text { Approximate age of diagnosis/occurrence of hypertension, diabetes, angina, MI, stroke, cancer or sudden } \\
\text { death, for each of mother, father, sister, brother, son and daughter }\end{array}$ \\
\hline $\begin{array}{l}\text { Ethnicity and other genetic related } \\
\text { information }\end{array}$ & $\begin{array}{l}\text { Place of birth, personal and parental ethnicity (e.g, Urdu, Punjabi, Pathan, Balooch, Sindhi, Memon, } \\
\text { Gujrati), parental co-sanguinity }\end{array}$ \\
\hline Socio-economic status & $\begin{array}{l}\text { Occupation(s), monthly income, level and duration of education, marital status, no. of dependants, } \\
\text { ownership/wealth }\end{array}$ \\
\hline Physical activity & $\begin{array}{l}\text { Type, frequency, duration and intensity of activity for each of occupational, work related commuting and } \\
\text { leisure time }\end{array}$ \\
\hline Tobacco consumption & See Table 2 for details \\
\hline Psychosocial factors & $\begin{array}{l}\text { Experience of traumatic events in the past year (e.g., loss of crop, family bereavement), perceived level of } \\
\text { occupational, domestic and financial stress, perceived level of mental and physical health }\end{array}$ \\
\hline Anthropometry & Height, weight, waist and hip circumference \\
\hline
\end{tabular}

HRT, hormone replacement therapy

Table 2 Information collected on dietary intake and tobacco consumption

\begin{tabular}{|c|c|c|}
\hline Type of food & Routinely recorded information & Additional information recorded to reflect local habits \\
\hline Cooking medium & Oil (recording type), butter, margarine & Ghee (type of fat) \\
\hline Breads & N/A & $\begin{array}{l}\text { Naan, chapatti (recording type of flour used), paratha (butter- } \\
\text { coated chapatti) }\end{array}$ \\
\hline Fruits and vegetables & $\begin{array}{l}\text { Separately for cooked and raw, green leafy } \\
\text { vegetables, yellow vegetables, cruciferous } \\
\text { vegetables, salad items, fruits }\end{array}$ & Method of cooking (grilled, curried and fried) \\
\hline Meats & Chicken, beef, mutton, lamb and fish & Method of cooking (grilled, curried and fried) \\
\hline Legumes & Nuts and seeds & Pulses (including different daals) \\
\hline Sweets & Bakery items & $\begin{array}{l}\text { Kheer (dairy based dessert), halwa, mithai, jalabe (unrefined } \\
\text { sugars), nimko (fried desserts) }\end{array}$ \\
\hline Brewed beverages & Tea, coffee, herbal tea & Qahwa (local form of herbal tea) \\
\hline Other beverages & $\begin{array}{l}\text { Milk, carbonated and non-carbonated soft drinks, } \\
\text { fruit juices }\end{array}$ & $\begin{array}{l}\text { Alcohol (including local varieties), lassi (yoghurt based drink, } \\
\text { recorded separately for sweet and salty) }\end{array}$ \\
\hline Tobacco consumption & $\begin{array}{l}\text { Usage status, quantity, frequency and lifetime. } \\
\text { Information on sources of passive smoking also } \\
\text { recorded }\end{array}$ & $\begin{array}{l}\text { For each of cigarettes, beedies (rolled tobacco), huqqa (water } \\
\text { pipe), paan (chewing tobacco), naswar (snuff), gutka and } \\
\text { supari (preparations of crushed betel nut, tobacco, and sweet } \\
\text { or savory flavourings). }\end{array}$ \\
\hline
\end{tabular}

onto the central database, which is securely held both in Karachi, Pakistan, and Cambridge, UK.

Collection of biological samples and initial biochemistry

Non-fasting blood samples (with the time since last meal recorded) have been drawn by phlebotomists from each participant and centrifuged within 45 min of venepuncture. In MI cases, blood sampling has been due to occur within
$24 \mathrm{~h}$ of the onset of MI symptoms and prior to the administration of any thrombolytics, with the time since onset of symptoms recorded to the nearest hour. Because blood is collected from MI cases while they are in a recumbent position (e.g, at about $45^{\circ}$ ), blood samples have been drawn in the same manner from controls to limit the possibility of systematic differences (e.g, plasma volumes may be higher in the supine position than when sitting [10, 11]). A total of $29 \mathrm{ml}$ of blood has been drawn from each participant in $2 \times 6 \mathrm{ml}$ serum tubes and $3 \times 5 \mathrm{ml}$ EDTA 
tubes (a further citrate tube has been obtained only in suspected MI cases for troponin assay). Hence, a total of five blood tubes have been collected per participant, including serum, EDTA plasma and whole blood which have been stored in cryogenic vials. All samples have been stored temporarily at each recruitment centre at $-20^{\circ} \mathrm{C}$. A second sample $(2 \mathrm{ml})$ has been drawn in cases $10 \mathrm{~h}$ after the onset of clinical symptoms for measurement of troponin. Serum, plasma and whole blood samples are transported daily to the local laboratory where they are stored at $-80^{\circ} \mathrm{C}$. The long-term $-80^{\circ} \mathrm{C}$ sample repository is kept in both Karachi and Cambridge. Measurement of total cholesterol (using an enzymatic colorimetric method, Roche Diagnostics $\mathrm{GmbH}$, USA) and high-density lipoproteincholesterol (using a homogeneous enzymatic colorimetric method, Roche Diagnostics GmbH, USA) has been completed in over 5,000 MI cases and over 5,000 controls thus far.

DNA quality, quantity and initial genotyping

Research technicians trained in accordance with standard operating procedures in laboratories in Karachi have extracted DNA from leucocytes using a reference phenolchloroform protocol [12]. PCR-RFLP has been performed in all samples on the day of extraction to provide an initial quality check. DNA concentrations have been determined by fluorescence measurement using PicoGreen molecular probes. The yield of DNA per participant has typically been between 600 and $800 \mathrm{ng} / \mu \mathrm{l}$ in a total volume of about $750 \mu \mathrm{l}$. To minimise any systematic biases arising from plate- or batch-specific genotyping error and/or nonrandom missingness, stock plates have been used to generate genotyping plates which contain a mixture of cases and controls along with negative and positive controls designed to address genotyping quality control (QC), plate identification and orientation. As part of the $\mathrm{QC}$, samples have been subject to molecular bar-coding and checked for degradation by running samples on agarose gels. Samples passing QC have been diluted in tris borate EDTA buffer to $50 \mathrm{ng} / \mu \mathrm{l}$ and arrayed into 96-well master plates.

Further expansion and measurements

By March 2009, PROMIS had recruited over 5,000 confirmed first-ever MI cases and over 5,000 controls. The main objectives of the study's next stages are: to expand the study to 20,000 MI cases and 20,000 controls; to enrich the bioresource in various ways in order to increase its scientific value; and to accelerate harvesting of its biological resources. Assays have been completed in the first 2,000 MI cases and in the first 2,000 controls of 45,000 genetic markers in 2,100 candidate genes in the Illumina

Table 3 Biological measurements in progress in PROMIS

\begin{tabular}{|c|c|c|}
\hline Approach & Analytical strategy & Potential value \\
\hline \multicolumn{3}{|l|}{ Genomics } \\
\hline Genomewide association study & $\begin{array}{l}\text { Illumina } 610 \text { quad array }+60 \mathrm{~K} \text { for } \\
\mathrm{CNV} \text { analysis }\end{array}$ & $\begin{array}{l}\text { (1) discovery of genetic variants associated with MI; (2) investigation } \\
\text { of genetic architecture in Pakistani population }\end{array}$ \\
\hline IBC Illumina cardiochip & $\begin{array}{l}45,000 \text { variants selected from } 2,100 \\
\text { candidate genes }\end{array}$ & Comprehensive evaluation of candidate genes in MI \\
\hline Sequencing & $\begin{array}{l}\text { In-depth sequencing to investigate LD } \\
\text { structure }\end{array}$ & Investigation of LD and haplotypes to identify causal genetic variants \\
\hline \multicolumn{3}{|l|}{ Transcriptomics } \\
\hline Genomewide expression study & $\begin{array}{l}\text { Illumina high throughput beadchip } \\
\text { platform ( } 46,000 \text { gene targets) }\end{array}$ & $\begin{array}{l}\text { (1) assessment of transcript levels associated with cis-acting sequence } \\
\text { variants; (2) comparison of resting and activated transcript levels in } \\
\text { cases and controls; (3) functional consequences of established and } \\
\text { novel variants }\end{array}$ \\
\hline Lmyphoblastoid cell lines & Transfection with Epstein-Barr virus & Functional genomics \\
\hline \multicolumn{3}{|l|}{ Metabonomics } \\
\hline Spectroscopy & 1H NMR and GC-MS & Metabolic determinants of MI \\
\hline \multicolumn{3}{|l|}{ Biomarkers } \\
\hline Circulating candidate analytes & $\begin{array}{l}\text { Total cholesterol, HDL-C, LDL-C, } \\
\text { triglycerides, apo-AI, apo-B, Lp(a), } \\
\text { CRP, Lp-PLA } 2 \text {, adiponectin }\end{array}$ & $\begin{array}{l}\text { (1) associations of biomarkers with MI; (2) genetic determinants of } \\
\text { the measured biomarkers in controls }\end{array}$ \\
\hline
\end{tabular}

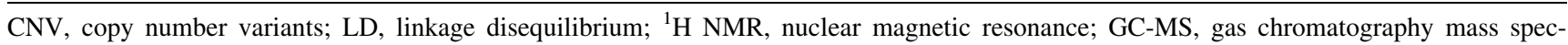
troscopy; HDL-C, high-density lipoprotein cholesterol; LDL-C, low-density lipoprotein cholesterol; apo-AI, apolipoprotein-A1; apo-B, apolipoprotein B100; Lp(a), lipoprotein (a); CRP, C-reactive protein; Lp-PLA 2 , Lipoprotein-associated phospholipase $\mathrm{A}_{2}$ 
IBC “cardiochip" array [13]. As part of WTCCC-2, a genomewide association scan (GWAS) has been conducted in the first 5,000 MI cases and in the first 5,000 controls using the Illumina 610-Quad array (including $>610,000$ SNPs plus 60,000 selected copy number variants) [14] (Table 3).

Serial epidemiological questionnaires, anthropometry, and blood sampling is planned in about 1,000 participants approximately 2-3 years after the initial visit, enabling quantification of and correction for regression dilution [15, 16]. Such resurveys should also help to validate further the food-frequency questionnaires developed for use in PROMIS. Pilot studies have already commenced to assess small metabolites and lipids by mass spectroscopy in plasma samples (Table 3) [17]. In a subset of participants who will be part of the GWAS, collection is planned of RNA samples from monocytes (e.g, Illumina High Throughput Beadchip platform with 46,000 gene targets) to enable study of the transcriptome and to elucidate mechanisms by which sequence variation causes change in gene expression $[18,19]$. In a subset of participants who will have both GWAS and gene expression data, collection is also planned of peripheral lymphocytes (using EasySep Human Selection kits, Stem Cell Technologies, London, UK) that will be transformed by Epstein-Barr virus for the establishment of permanent lymphoblastoid cell lines to enable functional experiments.

\section{Discussion}

Although Pakistan is experiencing a substantial increase in the burden of cardiovascular disease [2, 3], risk factors for CHD in this population have been relatively little studied $[3,5,6,20,21]$. Before PROMIS, the previous largest study was INTERHEART-Pakistan, which comprised 650 MI cases and 650 controls [8]. Whereas INTERHEART has assessed risk factors common to over 50 countries, the complementary approach in PROMIS has been to focus on these factors plus a more detailed assessment of distinctive exposures in Pakistan, notably: indigenous smoking modes (e.g., beedies, huqqa, naswar); dietary intake (e.g., ghee consumption, a major source of fat); and a history of consanguinity. By March 2009, PROMIS had recruited over 5,000 first-ever confirmed MI cases and over 5,000 controls in whom locally relevant exposure information had been recorded and from whom various biological samples had been collected, processed and stored.

PROMIS is addressing two distinct but related strategic needs. First, the study is estimating the impact of various modifiable risk factors for MI that should be of considerable relevance to the prevention and control of cardiovascular disease in Pakistan, including, as noted above, tobacco consumption, dietary intake, and physical activity [5, 6, 22, 23]. The second focus of PROMIS is to contribute to scientific (particularly genetic) discovery in an ethnicspecific context. Evidence is emerging of variation in the impact of risk factors in different racial groups, such as a two-fold higher odds ratios for MI with total cholesterol in South Asians than Europeans [24]; higher odds ratios for MI with the $L T A 4 H$ haplotype in Africans than Europeans [25]; and relevance of TCF7L2 to type 2 diabetes in West Africans but not East Asians [26, 27]. The value of large ethnic-specific studies is illustrated by discovery of the strongest common susceptibility locus (KCNQ1) yet for type 2 diabetes, identified in East Asians [28, 29] but not initially in Europeans because the allele frequency in East Asians is much higher (40\% vs. $5 \%$ ) despite similar odds ratios in both races [30]. This highlights how an ethnicspecific study like PROMIS should reveal entirely new loci, particularly for low-frequency causal alleles of more recent origin.

The potentially distinctive risk profile of South Asian populations [24], together with the apparently earlier onset of MI and greater familial clustering of CHD [6], reinforces the need to evaluate directly genetic and other risk factors in South Asia [1-4]. Despite this need, genetic investigation of CHD in South Asian populations has hitherto been limited. By early 2009 at least nine GWAS of clinical coronary outcomes had been reported, all of which had been conducted in populations of Northern European or Japanese ancestry (Table 4) [31-39]. None of these had adequate statistical power to detect reliably odds ratios with common variants of 1.5 or smaller. To our knowledge, at least three studies are currently conducting GWAS for CHD in South Asians: PROMIS (5,000 confirmed MI cases and 5,000 controls in urban Pakistan), LOLIPOP $(3,500$ cases of MI and/or coronary stenosis and 4,000 controls in London, UK) [40] and INTERHEART (400 MI cases and 400 controls in South Asia) [8]. These (and other) studies should yield novel insights into the genetic determinants of CHD in South Asians, particularly in potential eventual combined analyses of data. In addition to the GWAS, PROMIS is concomitantly attempting other discovery approaches (e.g, metabolomics employing ${ }^{1} \mathrm{H}$-nuclear magnetic resonance spectroscopy and gas-chromatography mass spectroscopy), and functional studies. Data from these complementary methods are likely to enhance biological insights, particularly with the application of emerging statistical techniques for systems biology [41, 42].

The strengths and potential limitations of PROMIS merit consideration. Retrospective case-control studies of MI can usefully complement prospective studies because the former involve ascertainment of exposure information and blood sampling of people who have already developed 


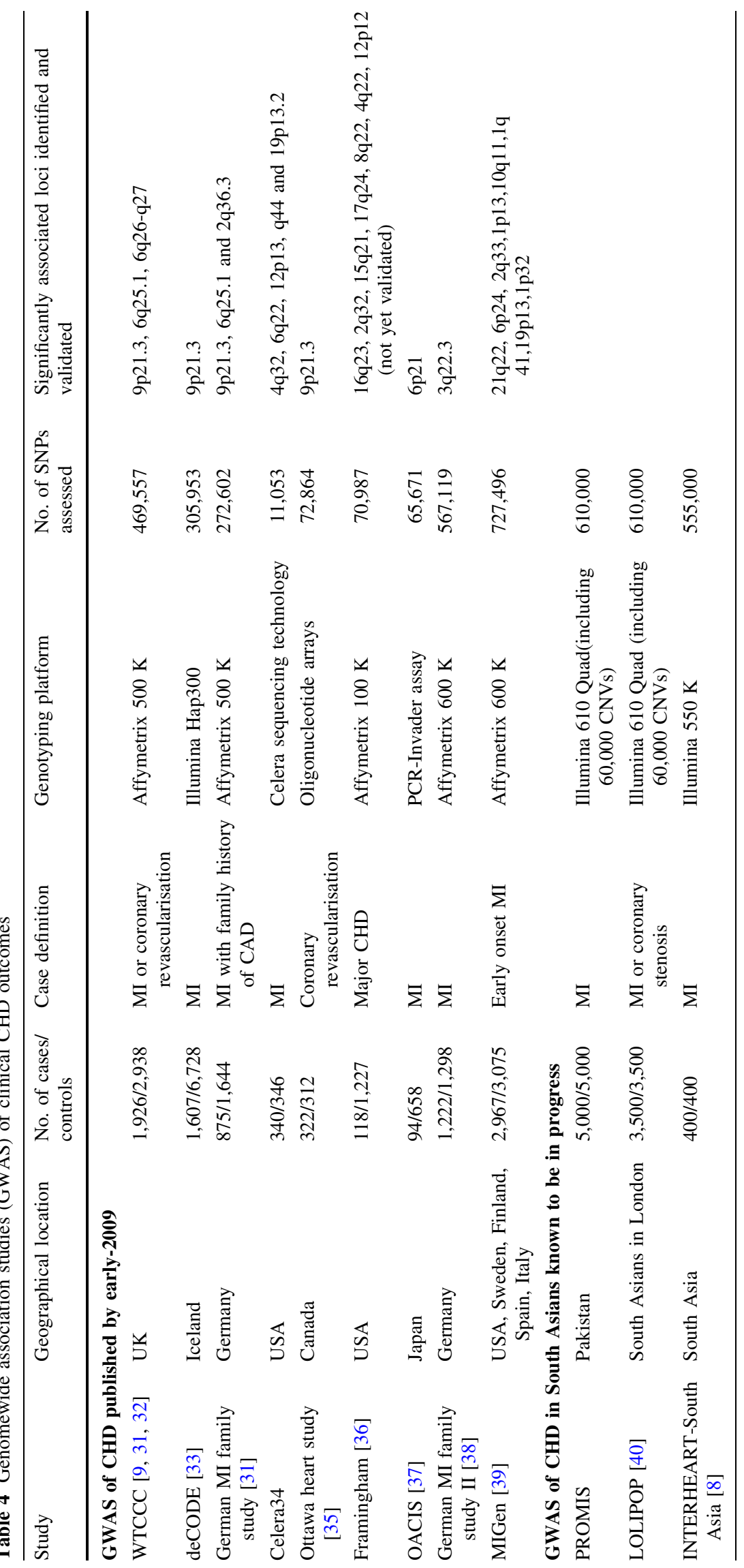


MI and a comparable group of controls without MI, enabling rapid and cost-effective accrual of large numbers of relevant cases. By contrast, prospective studies need several hundred thousand people to be screened (with all of their blood samples kept in frozen storage) and followed for at least one or two decades in order to accrue about 20,000 MI cases. Furthermore, retrospective studies are often able to include large numbers of individuals who have developed the disease at younger ages, when associations with risk factors are often stronger, providing particularly sensitive tests of certain hypotheses. As demonstrated by the WTCCC [9], case-control studies can powerfully and efficiently facilitate genetic discovery and can use GWAS data to quantify and robustly correct for any population structure [43].

The ISIS and INTERHEART studies have, moreover, demonstrated that appropriately conducted, large casecontrol studies can usefully address some nongenetic hypotheses in MI, such as tobacco and alcohol consumption, and serological evidence of infection [7-9, 44-46]. Nevertheless, particularly in relation to nongenetic hypotheses, retrospective case-control studies may be liable to potential biases, such as recall bias (although there may be less scope for such bias in a study of acute MI than in a study of chronic stable CHD, as hours rather than months or years have elapsed since the index event) and selection biases. As noted earlier, selection of controls in case-control studies invariably involves trade-offs between scientific rigor and feasibility. Following the example of INTERHEART [8], we have opted to recruit controls drawn from attendants of people visiting out-patient clinics or (non-blood-related) attendants of cardiac patients; these groups will be compared in sensitivity analyses. Studies of plasma components may be affected by case-control studies of acute MI because certain circulating markers may be altered by sampling of blood within $24 \mathrm{~h}$ of MI symptoms. If as in PROMIS, time since the onset of symptoms has been recorded, any material bias can be quantified and at least partially corrected for. Similar considerations apply to fasting status and the recording of time since last meal [7, 44].

\section{Conclusion}

PROMIS is a large epidemiological resource for CHD in South Asia that will be systematically harvested to help identify and evaluate genetic and other determinants of MI in South Asia. It should help to hasten discovery of diseasecausing pathways and to inform regionally appropriate strategies that optimise public health action in a country with limited resources.
Acknowledgements We would like to acknowledge the contributions of the following individuals: Epidemiological fieldwork in Pakistan: Mustafa Hussain, Muhammad Fahim, Asim Saleem, Kishore Kumar, Kishwar Kumar, Muhammad Zuhair Yusuf, Shahid Abbas, Aftab Alam Gul, Junaid Zafar, Faisal Shahid, Shahzad Majeed Bhatti, Zahir Hussain, Kanwal Amir, Turkey Hussain Marmoos, Faud Khurshid, Farhat Abdul Muntaqim, Sarosh Fatima, Rehan Ahmed, Muhammad Nabeel, Mansoor Ahmed Khokar, Syed Shazad Hussain, Madad Ali Ujjan, Parveen Sultan, Asghar Ali, Ayaz Ali, Mir Alam, Hassan Zaib, Abdul Ghafoor, Saeed Ahmed, Muhammad Riazuddin, Muhammad Irshad Javed, Jabir Furqan, Abdul Ghaffar, Muhammad Shahid, Tanveer Baig Mirza, Zeeshan Ozair, Fahad Shuja, Mustafa Qadir Hameed, Hamza Khalid, Imad Hussain, Ali Kazmi, Ayesha Sajjad, Ali Memon and Anwar Ali Siddiqui. Laboratory assays: Nasir Sheikh, Shaheen Khanum, Shajjia Razi Hyder, Mehwish Jabar, Zahid Hussain, Ernst Schaefer, Monaa Zafar, Inosh Hasan, Julian Griffin. Data management: Sarfaraz Sher Ali, Touqeer Ahmed, Fariha Nadeem, Matthew Walker, Sarah Watson. Epidemiological/statistical support: Stephen Kaptoge, Emanuele Di Angelantonio, Alexander Thompson, Kausik Ray, Nicole Soranzo, Myriam Scherman-Alexander, Philip Haycock, Rajiv Chowdhury, Sebhat Erqou, Reeta Gobin, Frances Wensley, Rao Kondapally Seshasai, Willem Ouwehand, Nilesh Samani. Administration: Hannah Sneath, Zehra Siddiqi, Angela Harper, Gulafroze Fazli, Kashif Saleheen, Hillary Fernandes. PROMIS was previously known as Cardiovascular Risk factors Identification in Karachi-CRIK.

Funding Epidemiological fieldwork in PROMIS has been supported by unrestricted grants to investigators at the University of Cambridge. The Wellcome Trust has supported a genomewide association scan and other genetic analyses. The British Heart Foundation has supported assays of several candidate biochemical analytes. The Cambridge Commonwealth Society supports Dr. Saleheen. The cardiovascular disease epidemiology group of Professor Danesh is underpinned by programme grants from the British Heart Foundation and the UK Medical Research Council.

Open Access This article is distributed under the terms of the Creative Commons Attribution Noncommercial License which permits any noncommercial use, distribution, and reproduction in any medium, provided the original author(s) and source are credited.

\section{References}

1. Mathers CD, Loncar D. Projections of global mortality and burden of disease from 2002 to 2030. PLoS Med. 2006;3(11):e442. doi:10.1371/journal.pmed.0030442.

2. Abegunde DO, Mathers CD, Adam T, Ortegon M, Strong K. The burden and costs of chronic diseases in low-income and middleincome countries. Lancet. 2007;370(9603):1929-38. doi:10.1016/ S0140-6736(07)61696-1.

3. Ghaffar A, Reddy KS, Singhi M. Burden of non-communicable diseases in South Asia. BMJ. 2004;328(7443):807-10. doi: 10.1136/bmj.328.7443.807.

4. McKeigue PM, Miller GJ, Marmot MG. Coronary heart disease in South Asians overseas: a review. J Clin Epidemiol. 1989;42(7):597-609. doi:10.1016/0895-4356(89)90002-4.

5. Gupta M, Brister S. Is South Asian ethnicity an independent cardiovascular risk factor? Can J Cardiol. 2006;22(3):193-7.

6. Ismail J, Jafar TH, Jafary FH, White F, Faruqui AM, Chaturvedi N. Risk factors for non-fatal myocardial infarction in young South Asian adults. Heart. 2004;90(3):259-63. doi:10.1136/hrt. 2003.013631. 
7. Parish S, Collins R, Peto R, Youngman L, Barton J, Jayne K, et al. Cigarette smoking, tar yields, and non-fatal myocardial infarction: 14, 000 cases and 32, 000 controls in the United Kingdom. The International Studies of Infarct Survival (ISIS) Collaborators. BMJ. 1995;311(7003):471-7.

8. Yusuf S, Hawken S, Ounpuu S, Dans T, Avezum A, Lanas F, et al. Effect of potentially modifiable risk factors associated with myocardial infarction in 52 countries (the INTERHEART study): case-control study. Lancet. 2004;364(9438):937-52. doi:10.1016/ S0140-6736(04)17018-9.

9. Wellcome Trust Case Control Consortium. Genome-wide association study of 14, 000 cases of seven common diseases and 3, 000 shared controls. Nature. 2007;447(7145):661-78. doi: 10.1038/nature05911.

10. Miller M, Bachorik PS, Cloey TA. Normal variation of plasma lipoproteins: postural effects on plasma concentrations of lipids, lipoproteins, and apolipoproteins. Clin Chem. 1992;38(4):56974.

11. Hagan RD, Upton SJ, Avakian EV, Grundy S. Increases in serum lipid and lipoprotein levels with movement from the supine to standing position in adult men and women. Prev Med. 1986;15(1):18-27. doi:10.1016/0091-7435(86)90032-0.

12. Saleheen D, Bukhari S, Haider SR, Nazir A, Khanum S, Shafqat $\mathrm{S}$, et al. Association of phosphodiesterase 4D gene with ischemic stroke in a Pakistani population. Stroke. 2005;36(10):2275-7. doi:10.1161/01.STR.0000182242.59466.ee.

13. Keating BJ, Tischfield S, Murray SS, Bhangale T, Price TS, Glessner JT, Galver L, Barrett JC, Grant SF, Farlow DN, Chandrupatla HR, Hansen M, Ajmal S, Papanicolaou GJ, Guo Y, Li M, Derohannessian S, de Bakker PI, Bailey SD, Montpetit A, Edmondson AC, Taylor K, Gai X, Wang SS, Fornage M, Shaikh T, Groop L, Boehnke M, Hall AS, Hattersley AT, Frackelton E, Patterson N, Chiang CW, Kim CE, Fabsitz RR, Ouwehand W, Price AL, Munroe P, Caulfield M, Drake T, Boerwinkle E, Reich D, Whitehead AS, Cappola TP, Samani NJ, Lusis AJ, Schadt E, Wilson JG, Koenig W, McCarthy MI, Kathiresan S, Gabriel SB, Hakonarson H, Anand SS, Reilly M, Engert JC, Nickerson DA, Rader DJ, Hirschhorn JN, Fitzgerald GA. Concept, design and implementation of a cardiovasular gene-centric $50 \mathrm{k}$ SNP array for large-scale genomic association studies. PLoS One. 2008;3(10):e3583. doi:10.1371/journal.pone.0003583.

14. DNA analysis solutions: human610-quad DNA analysis beadchip http://www.illumina.com/pages.ilmn?ID=248.

15. Clarke R, Shipley M, Lewington S, Youngman L, Collins R, Marmot $\mathrm{M}$, et al. Underestimation of risk associations due to regression dilution in long-term follow-up of prospective studies. Am J Epidemiol. 1999;150(4):341-53.

16. Fibrinogen Studies Collaboration, Wood AM, White I, Thompson SG, Lewington S, Danesh J. Regression dilution methods for meta-analysis: assessing long-term variability in plasma fibrinogen among 27, 247 adults in 15 prospective studies. Int $\mathbf{J}$ Epidemiol. 2006;35(6):1570-8. doi:10.1093/ije/dyl233.

17. Holmes E, Loo RL, Stamler J, Bictash M, Yap IK, Chan Q, et al. Human metabolic phenotype diversity and its association with diet and blood pressure. Nature. 2008;453(7193):396-400. doi: 10.1038/nature06882.

18. Rebbeck TR, Spitz M, Wu X. Assessing the function of genetic variants in candidate gene association studies. Nat Rev Genet. 2004;5(8):589-97. doi:10.1038/nrg1403.

19. Nürnberg P, Roewer L, Neitzel H, Sperling K, Pöpperl A, Hundrieser J, et al. DNA fingerprinting with the oligonucleotide probe (CAC)5/(GTG)5: somatic stability and germline mutations. Hum Genet. 1989;84(1):75-8. doi:10.1007/BF00210676.

20. Pais P, Pogue J, Gerstein H, Zachariah E, Savitha D, Jayprakash $S$, et al. Risk factors for acute myocardial infarction in Indians: a case-control study. Lancet. 1996;348(9024):358-63. doi: 10.1016/S0140-6736(96)02507-X.

21. Patil SS, Joshi R, Gupta G, Reddy MV, Pai M, Kalantri SP. Risk factors for acute myocardial infarction in a rural population of central India: a hospital-based case-control study. Natl Med J India. 2004;17(4):189-94.

22. Nishtar S, Wierzbicki AS, Lumb PJ, Lambert-Hammill M, Turner $\mathrm{CN}$, Crook MA, et al. Waist-hip ratio and low HDL predict the risk of coronary artery disease in Pakistanis. Curr Med Res Opin. 2004;20(1):55-62. doi:10.1185/030079903125002595.

23. Saleheen D, Frossard P. CAD risk factors and acute myocardial infarction in Pakistan. Acta Cardiol. 2004;59(4):417-24. doi: 10.2143/AC.59.4.2005208.

24. McQueen MJ, Hawken S, Wang X, Ounpuu S, Sniderman A, Probstfield J, et al. Lipids, lipoproteins, and apolipoproteins as risk markers of myocardial infarction in 52 countries (the INTERHEART study): a case-control study. Lancet. 2008;372 (9634):224-33. doi:10.1016/S0140-6736(08)61076-4.

25. Helgadottir A, Manolescu A, Helgason A, Thorleifsson G, Thorsteinsdottir U, Gudbjartsson DF, et al. A variant of the gene encoding leukotriene A4 hydrolase confers ethnicity-specific risk of myocardial infarction. Nat Genet. 2006;38(1):68-74. doi: $10.1038 / n g 1692$.

26. Working NCINHGRI. Group on Replication in Association Studies, Chanock SJ, Manolio T, Boehnke M, Boerwinkle E, Hunter DJ, Thomas G, Hirschhorn JN, Abecasis G, Altshuler D, Bailey-Wilson JE, Brooks LD, Cardon LR, Daly M, Donnelly P, Fraumeni JF Jr, Freimer NB, Gerhard DS, Gunter C, Guttmacher AE, Guyer MS, Harris EL, Hoh J, Hoover R, Kong CA, Merikangas KR, Morton CC, Palmer LJ, Phimister E.G, Rice JP, Roberts J, Rotimi C, Tucker MA, Vogan KJ, Wacholder S, Wijsman EM, Winn DM, Collins FS. Replicating genotype-phenotype associations. Nature. 2007;447(7145):655-60. doi: 10.1038/447655a.

27. Helgason A, Pálsson S, Thorleifsson G, Grant SF, Emilsson V, Gunnarsdottir S, et al. Refining the impact of TCF7L2 gene variants on type 2 diabetes and adaptive evolution. Nat Genet. 2007;39(2):218-25. doi:10.1038/ng1960.

28. Yasuda K, Miyake K, Horikawa Y, Hara K, Osawa H, Furuta H, et al. Variants in KCNQ1 are associated with susceptibility to type 2 diabetes mellitus. Nat Genet. 2008;40(9):1092-7.

29. Unoki H, Takahashi A, Kawaguchi T, Hara K, Horikoshi M, Andersen G, et al. SNPs in KCNQ1 are associated with susceptibility to type 2 diabetes in East Asian and European populations. Nat Genet. 2008;40(9):1098-102.

30. Zeggini E, Scott LJ, Saxena R, Voight BF, Marchini JL, Hu T, et al. Meta-analysis of genome-wide association data and largescale replication identifies additional susceptibility loci for type 2 diabetes. Nat Genet. 2008;40(5):638-45. doi:10.1038/ng.120.

31. Samani NJ, Erdmann J, Hall AS, Hengstenberg C, Mangino M, Mayer B, Dixon RJ, Meitinger T, Braund P, Wichmann HE, Barrett JH, König IR, Stevens SE, Szymczak S, Tregouet DA, Iles MM, Pahlke F, Pollard H, Lieb W, Cambien F, Fischer M, Ouwehand W, Blankenberg S, Balmforth AJ, Baessler A, Ball SG, Strom TM, Braenne I, Gieger C, Deloukas P, Tobin MD, Ziegler A, Thompson JR, Schunkert H, WTCCC and the Cardiogenics Consortium. Genomewide association analysis of coronary artery disease. N Engl J Med. 2007;357(5):443-53. doi: 10.1056/NEJMoa072366.

32. Trégouët DA, König IR, Erdmann J, Munteanu A, Braund PS, Hall AS, Grosshennig A, Linsel-Nitschke P, Perret C, DeSuremain M, Meitinger T, Wright BJ, Preuss M, Balmforth AJ, Ball SG, Meisinger C, Germain C, Evans A, Arveiler D, Luc G, Ruidavets JB, Morrison C, van der Harst P, Schreiber S, Neureuther K, Schäfer A, Bugert P, El Mokhtari NE, Schrezenmeir J, 
Stark K, Rubin D, Wichmann HE, Hengstenberg C, Ouwehand W, Wellcome Trust Case Control Consortium. Cardiogenics Consortium, Ziegler A, Tiret L, Thompson JR, Cambien F, Schunkert H, Samani NJ. Genome-wide haplotype association study identifies the SLC22A3-LPAL2-LPA gene cluster as a risk locus for coronary artery disease. Nat Genet. 2009;41(3):283-5. doi:10.1038/ng.314.

33. Helgadottir A, Thorleifsson G, Manolescu A, Gretarsdottir S, Blondal T, Jonasdottir A, et al. A common variant on chromosome 9p21 affects the risk of myocardial infarction. Science. 2007;316(5830):1491-3. doi:10.1126/science.1142842.

34. Shiffman D, Ellis SG, Rowland CM, Malloy MJ, Luke MM, Iakoubova OA, et al. Identification of four gene variants associated with myocardial infarction. Am J Hum Genet. 2005;77(4):596-605. doi:10.1086/491674.

35. McPherson R, Pertsemlidis A, Kavaslar N, Stewart A, Roberts R, Cox DR, et al. A common allele on chromosome 9 associated with coronary heart disease. Science. 2007;316(5830):1488-91. doi:10.1126/science.1142447.

36. Larson MG, Atwood LD, Benjamin EJ, Cupples LA, D’Agostino RB Sr, Fox CS, et al. Framingham heart study $100 \mathrm{~K}$ project: genome-wide associations for cardiovascular disease outcomes. BMC Med Genet. 2007;8(Suppl 1):S5. doi:10.1186/1471-23508-S1-S5.

37. Ozaki K, Ohnishi Y, Iida A, Sekine A, Yamada R, Tsunoda T, et al. Functional SNPs in the lymphotoxin-alpha gene that are associated with susceptibility to myocardial infarction. Nat Genet. 2002;32(4):650-4. doi:10.1038/ng1047.

38. Erdmann J, Grosshennig A, Braund PS, König IR, Hengstenberg C, Hall AS, Linsel-Nitschke P, Kathiresan S, Wright B, Trégouët DA, Cambien F, Bruse P, Aherrahrou Z, Wagner AK, Stark K, Schwartz SM, Salomaa V, Elosua R, Melander O, Voight BF, O'Donnell CJ, Peltonen L, Siscovick DS, Altshuler D, Merlini PA, Peyvandi F, Bernardinelli L, Ardissino D, Schillert A, Blankenberg S, Zeller T, Wild P, Schwarz DF, Tiret L, Perret C, Schreiber S, El Mokhtari NE, Schäfer A, März W, Renner W, Bugert P, Klüter H, Schrezenmeir J, Rubin D, Ball SG, Balmforth AJ, Wichmann HE, Meitinger T, Fischer M, Meisinger C, Baumert J, Peters A, Ouwehand WH, Italian Atherosclerosis, Thrombosis, and Vascular Biology Working Group. Myocardial Infarction Genetics Consortium; Wellcome Trust Case Control Consortium; Cardiogenics Consortium, Deloukas P, Thompson JR, Ziegler A, Samani NJ, Schunkert H. New susceptibility locus for coronary artery disease on chromosome 3q22.3. Nat Genet. 2009;41(3):280-2. doi:10.1038/ng.307.

39. Myocardial Infarction Genetics Consortium, Kathiresan S, Voight BF, Purcell S, Musunuru K, Ardissino D, Mannucci PM, Anand S, Engert JC, Samani NJ, Schunkert H, Erdmann J, Reilly MP, Rader DJ, Morgan T, Spertus JA, Stoll M, Girelli D, McKeown PP, Patterson CC, Siscovick DS, O’Donnell CJ, Elosua R, Peltonen L, Salomaa V, Schwartz SM, Melander O, Altshuler D, Ardissino D, Merlini PA, Berzuini C, Bernardinelli L, Peyvandi F, Tubaro M, Celli P, Ferrario M, Fetiveau R, Marziliano N, Casari G, Galli M, Ribichini F, Rossi M, Bernardi F, Zonzin P, Piazza A, Mannucci PM, Schwartz SM, Siscovick DS, Yee J, Friedlander Y, Elosua R, Marrugat J, Lucas G, Subirana I, Sala J, Ramos R, Kathiresan S, Meigs JB, Williams G,
Nathan DM, MacRae CA, O’Donnell CJ, Salomaa V, Havulinna AS, Peltonen L, Melander O, Berglund G, Voight BF, Kathiresan S, Hirschhorn JN, Asselta R, Duga S, Spreafico M, Musunuru K, Daly MJ, Purcell S, Voight BF, Purcell S, Nemesh J, Korn JM, McCarroll SA, Schwartz SM, Yee J, Kathiresan S, Lucas G, Subirana I, Elosua R, Surti A, Guiducci C, Gianniny L, Mirel D, Parkin M, Burtt N, Gabriel SB, Samani NJ, Thompson JR, Braund PS, Wright BJ, Balmforth AJ, Ball SG, Hall AS; Wellcome Trust Case Control Consortium, Schunkert H, Erdmann J, LinselNitschke P, Lieb W, Ziegler A, König I, Hengstenberg C, Fischer M, Stark K, Grosshennig A, Preuss M, Wichmann HE, Schreiber S, Schunkert H, Samani NJ, Erdmann J, Ouwehand W, Hengstenberg C, Deloukas P, Scholz M, Cambien F, Reilly MP, Li M, Chen Z, Wilensky R, Matthai W, Qasim A, Hakonarson HH, Devaney J, Burnett MS, Pichard AD, Kent KM, Satler L, Lindsay JM, Waksman R, Epstein SE, Rader DJ, Scheffold T, Berger K, Stoll M, Huge A, Girelli D, Martinelli N, Olivieri O, Corrocher R, Morgan T, Spertus JA, McKeown P, Patterson CC, Schunkert H, Erdmann E, Linsel-Nitschke P, Lieb W, Ziegler A, König IR, Hengstenberg C, Fischer M, Stark K, Grosshennig A, Preuss M, Wichmann HE, Schreiber S, Hólm H, Thorleifsson G, Thorsteinsdottir U, Stefansson K, Engert JC, Do R, Xie C, Anand S, Kathiresan S, Ardissino D, Mannucci PM, Siscovick D, O'Donnell CJ, Samani NJ, Melander O, Elosua R, Peltonen L, Salomaa V, Schwartz SM, Altshuler D . Genome-wide association of early-onset myocardial infarction with single nucleotide polymorphisms and copy number variants. Nat Genet. 2009;41(3): 334-41.

40. Chambers JC, Elliott P, Zabaneh D, Zhang W, Li Y, Froguel P, et al. Common genetic variation near MC4R is associated with waist circumference and insulin resistance. Nat Genet. 2008; 40(6):716-8. doi:10.1038/ng.156.

41. Marjoram P, Tavaré S. Modern computational approaches for analysing molecular genetic variation data. Nat Rev Genet. 2006;7(10):759-70. doi:10.1038/nrg1961.

42. Kimura H, Okano H, Tanaka RJ. Stochastic approach to molecular interactions and computational theory of metabolic and genetic regulations. J Theor Biol. 2007;248(4):590-607. doi: 10.1016/j.jtbi.2007.06.017.

43. Patterson N, Price AL, Reich D. Pulation structure and eigenanalysis. PLoS Genet. 2006;2(12):e190. doi:10.1371/journal. pgen.0020190.

44. Teo KK, Ounpuu S, Hawken S, Pandey MR, Valentin V, Hunt D, et al. Tobacco use and risk of myocardial infarction in 52 countries in the INTERHEART study: a case-control study. Lancet. 2006;368(9536):647-58. doi:10.1016/S0140-6736(06) 69249-0.

45. Rosengren A, Hawken S, Ounpuu S, Sliwa K, Zubaid M, Almahmeed WA, et al. Association of psychosocial risk factors with risk of acute myocardial infarction in 11119 cases and 13648 controls from 52 countries (the INTERHEART study): casecontrol study. Lancet. 2004;364(9438):953-62. doi:10.1016/ S0140-6736(04)17019-0.

46. Danesh J, Youngman L, Clark S, Parish S, Peto R, Collins R. Helicobacter pylori infection and early onset myocardial infarction: case-control and sibling pairs study. BMJ. 1999;319 (7218):1157-62. 